\title{
Descriptive Body Composition Profile in Female Olympic Volleyball Medalists Defined Using Multichannel Bioimpedance Measurement: Rio 2016 Team Case Study
}

\author{
Perfil Descriptivo de la Composición Corporal en Medallistas Femeninos de Voleibol Olímpico \\ Definido Mediante Medición de Bioimpedancia Multicanal: Estudio del Equipo Rio 2016
}

\author{
Bankovic, V. ${ }^{1}$; Dopsaj, M. ${ }^{2}$; Terzic, Z. ${ }^{1}$ \& Nesic, G. ${ }^{3}$
}

BANKOVIC, V.; DOPSAJ, M.; TERZIC, Z. \& NESIC, G. Descriptive body composition profile in female olympic volleyball medalists defined using multichannel bioimpedance measurement: Rio 2016 team case study. Int. J. Morphol., 36(2):699-708, 2018.

SUMMARY: The subject of this paper was the study of the morphological status of top elite women volleyball players, Rio 2016 Olympic medal winners, with the aim of obtaining reliable quantitative data, used to determine the morphological model and to control the morphological status of top elite women volleyball players. This study tested 12 top elite women volleyball players who participated in the 2016 Rio Olympic Games and won the silver medal. Measurements of body composition were conducted one day before departing for the Rio Olympic Games, on 25th June, 2016, using electrical bioimpendance analysis (BIA), with the InBody 720 Tetrapolar 8-Point Tactile Electrode System analyzer. The study included 29 variables: 17 original variables, four voluminosity-dependent variables, six longitudinality-dependent variables, and two combined index variables. The results showed that average height of the women players was $188.93 \pm 6.49 \mathrm{~cm}$, the overall mean BM value for the Serbian team was $75.56 \pm 6.97$, the overall mean BMI value for the team was $21.08 \pm 1.30 \mathrm{~kg} \bullet \mathrm{m}^{-2}$, while the mean values for percent skeletal muscles and body mass were $48.95 \pm 1.78 \%$ and $13.43 \pm 2.70 \%$, respectively. Upon a thorough analysis of the results of the study, it can be argued that in all measured anthropomorphological characteristics the top elite women volleyball players from the tested sample had a body type of remarkable basic longitudinality, i.e., BH, and a body composition mainly characterized by very high muscle mass but such a low amount of body fat that it bordered on the biological minimum for women.

KEY WORDS: Bioelectrical impedance; Female athletes; Volleyball; Body composition.

\section{INTRODUCTION}

Achieving the top result at a sports competition depends on a combination of several factors, such as superior player selection, an adequately optimal training process, and permanent control, i.e., monitoring all relevant parameters that may have an impact on reaching the peak competition form at the required moment. Without doubt, one of the most important factors in the technology of sports training of top athletes is the quantification of the body composition. It is exactly the knowledge of these quantities that plays an important role in the process of monitoring both the athletic performance and the training process (Ackland et al., 2012).

Generally, the selection of players for the given sport represents the first methodological step in the competitive phase of the sports training system. There is clear scientific evidence of a strong relationship between morphological characteristics and the chosen sport (Eston \& Reilly, 2009; Norton \& Olds, 2001). Also, it is one of the selection mechanisms that young athletes decide for a sport that suits their morphology, because, in spatial sense, this becomes their advantage in the chosen sport or discipline (Santos et $a l ., 2014)$. On the other hand, sports training on its own, causes biological adaptations triggered by the training load, in terms of emphasizing the morphological characteristics typical of the chosen sport or discipline, or of the particular playing position on the team in the case of sports games. With respect to volleyball, it has been shown that the higher the sports achievements are, the more closely related they are to the athlete's body composition and build (Santos et

\footnotetext{
${ }^{1}$ Volleyball Federation of Serbia, Terazije 35/II, 11000 Belgrade, Serbia.

${ }^{2}$ Department of Analysis and Diagnosis in Sport, University of Belgrade Faculty of Sport and Physical Education, Blagoja Parovica 156, 11030 Belgrade, Serbia.

${ }^{3}$ Department of Volleyball, University of Belgrade Faculty of Sport and Physical Education, Blagoja Parovica 156, 11030 Belgrade, Serbia.
} 
al.). Therefore, considerable attention is paid in most sports to monitoring and studying the anthropological status, i.e., the characteristics of the body structure in both active athletes and those who intend to participate in a sport (Ackland et al.; Dopsaj et al., 2017).

Volleyball is a sport in which the most prominent body characteristic, besides physical abilities such as agility, reaction speed, movement speed, or aerobic and alactic power, is longitudinality (Norton \& Olds; Schaun et al., 2013; Palao et al., 2014). Moreover, due to the specificity of game play, there are variations relative to different playing positions in both physical stature and the morphological structure of players within the team (Malousaris et al., 2008; Mielgo-Ayuso et al., 2015). Such variability is more pronounced in women's volleyball than in men's, especially considering morphological parameters (Maly, 2009; Malá et al., 2010). This could result from the selection of women players for certain positions on the team, as well as their specificities in the performance of particular motor tasks. From the early selection, very tall players are directed towards the specialization in the position of middle blocker, which involves specific performance of the technique as well as the number of motor tasks that the player must realize. Also, considering the specialist position of Libero in volleyball, these players mostly participate in defense tasks (without motor tasks of jumping), so that in most teams the players of this specialization unjustifiably lack in adequately developed abilities, i.e., training loads aimed at force development and speed power (jumps). It can often be seen that, when their morphological status is compared with players of other specializations, there are great deviations in the absolute muscle mass: Libero is usually the shortest player on the team with the lowest body mass, hence with the lowest percentage of muscle mass (Malousaris et al.).

For these reasons, there is a need in modern sports science to establish specialized models that will also describe the morphological characteristics in top athletes (Norton \& Olds; Dopsaj et al., 2017), and subsequently, top volleyball players (Gabbett et al., 2007; Nikolaidis et al., 2012). By defining the model characteristics, it is possible to monitor deviations relative to the different stages of the training cycle and to the influence of specific factors (travel, changing time zones, the environment, or competitions) on the morphological status of women players. A better understanding of the variability in the characteristics of the body structure throughout the season with respect to a player's performance, competitive achievement, and potentially the whole career, will provide a valid scientific basis for facilitating a positive influence, aimed primarily at improving the morphological profile in individual players and mitigating the negative effects that cause it to change.
Finally, it will be possible to establish set patterns that define the morphological space occupied by women volleyball players on different competitive levels (Malousaris et al.; Malá et al.; Dopsaj \& Djordjevic-Nikic, 2016).

The subject of this paper was the study of the morphological status of top elite women volleyball players, Rio 2016 Olympic medal winners. The aim of the study was to define the model of body composition in elite women volleyball players using multichannel segmental bioelectric impedance as the method of measurement. The study aimed to obtain reliable quantitative data to be used in the process of determining the morphological model and controlling the morphological status of elite women volleyball players.

The results obtained and the body composition model defined in the study can further be used to lay the foundations for the system of monitoring the quantitative characteristics in elite women volleyball players during the main competition season of the Olympic cycle. Also, the given model setup will enable the definition of the rules pertaining to the system of change control, the identification of the effects of training and competition processes on the adaptation mechanisms, as well as the impact of the exposure to positive or negative effects produced by frequent changes in diet or time zones, and the specificity of competition categories and playing positions relative to both total body composition and its particular components.

\section{MATERIAL AND METHOD}

This research belongs to the category of natural experiments; it is a team case study of an elite sports team. With respect to the form, this study has charasteristics of fundamental and applicative research as it provides new insights in the area of general understanding of body structure in elite women volleyball players participating in top competitions.

Respondent Sample. The research respondent sample included 12 female elite athletes, members of the Serbian women's volleyball team who won the silver medal at the Olympic Games in Rio de Janeiro in 2016. The players played in the following positions: Setter (2), Opposite Hitter (2), Outside Hitter (4), Middle Blocker (3), and Libero (1). The players' age was 26.8 \pm 3.9 years $(\mathrm{Min}-\mathrm{Max}=20.5-$ 34.5 years), while the years of training were $15.3 \pm 4.1$ years (Min $-\operatorname{Max}=8.5-22.6$ years).

All players were informed about the procedures and conditions of testing and volunteered to participate in this 
research. The measurementof body composition was carried out on June 25, 2016, one day before leaving for the Rio Olympic Games, in the scientific research laboratory of University of Belgrade Faculty of Sport and Physical Education. The research was conducted in accordance with the Helsinki Declaration: Recommendations Guiding Physicians in Biomedical Research Involving Human Subjects (http://www.cirp.org/library/ethics/helsinki/), and with the approval and consent of the Ethics Commission of University of Belgrade Faculty of Sport and Physical Education.

Measurements. Measurements of the body composition were conducted using electrical bioimpendance analysis (BIA), with the InBody 720 Tetrapolar 8-Point Tactile Electrode System (Biospace Co., Ltd). InBody 720 analyzer (720 Inbody Biospace 2008) uses the DSMBIA (Direct Segmental Multi-Frequency Bioelectrical Impedance Analysis) technology for measuring the body structure, which has been found to be highly statistically reliable and valid for measurements of both overall and segmental body composition in female athletes (Formetti et al., 1999; Esco et al., 2015).

All respondents were measured according to the suggestions of the device manufacturer, as well as in accordance with the standards and procedures explained earlier (InBody720, 2008; Dopsaj et al., 2015). In summary, $48 \mathrm{~h}$ before the measurement, the players had only four lightweight training sessions low in workload and intensity, each lasting for up to $60 \mathrm{~min}$, while the measurement was carried out before breakfast and morning training.

Variables. The definition of the players' body composition took into account four types of variables. Besides the primary body composition variables, there were three types of index variables: voluminosity-dependent, longitudinalitydependent, and combined body composition index variables. Thus, the respondents, who in their sports performance belonged to the category of top elite athletes, were described in relation to different aspects of the structure of body dimensionality.

This study included 29 variables: 17 primary variables, four voluminosity-dependent variables, six longitudinality-dependent variables, and two combined index variables. The variables used were as follows (Kyle et al., 2001; Santos et al.; Dopsaj et al., 2015; Dopsaj \& DjordjevicNikic; Dopsaj et al., 2017):

\footnotetext{
1. Primary body composition variables

- $\mathrm{BH}$ - body height, expressed in $\mathrm{cm}$;

$\mathrm{BM}$ - body mass, expressed in $\mathrm{kg}$;
}

- TBW - total body water;

FFM - fat-free (lean) body mass, expressed in kg;

Protein - total body protein, expressed in $\mathrm{kg}$;

BFM - body fat mass, expressed in kg;

SMM - skeletal muscle mass, expressed in $\mathrm{kg}$;

RAM - right arm lean mass, expressed in $\mathrm{kg}$;

RAF - total right arm fat mass, expressed in $\mathrm{kg}$;

- LAM - left arm lean mass, expressed in kg;

- LAF - total left arm fat mass, expressed in $\mathrm{kg}$;

- Trunk LM - trunk lean mass, expressed in $\mathrm{kg}$;

- Trunk FM - total trunk fat mass, expressed in kg;

- RLM - right leg lean mass, expressed in $\mathrm{kg}$;

- RLF - total right leg fat mass, expressed in $\mathrm{kg}$;

- LLM - left leg lean mass, expressed in kg;

- LLF - total left leg fat mass, expressed in $\mathrm{kg}$.

2. Longitudality-dependent body composition variables - BMI - body mass index, expressed in $\mathrm{kg} / \mathrm{m}^{2}$;

- FFMI - fat-free (lean) body mass index, expressed in $\mathrm{kg} / \mathrm{m}^{2}$;

- PFMI - body protein fat mass index, expressed in $\mathrm{kg} / \mathrm{m}^{2}$;

- BFMI - body fat mass index, expressed in $\mathrm{kg} / \mathrm{m}^{2}$;

- SMMI - body skeletal muscle mass index, expressed in $\mathrm{kg} / \mathrm{m}^{2}$;

- PMI - body protein mass index, expressed in $\mathrm{kg} / \mathrm{m}^{2}$.

3. Voluminosity-dependent body composition variables - PBFM - percent of body fat mass, expressed in \%;

- PTBW - percent of total body water, expressed in \%;

- PSMM - percent of skeletal muscle mass index, expressed in \%;

. PPM - percent of protein mass, expressed in \%.

4. Combined body composition index variables

- PBF/BMI - percent of body fat and body mass ratio index, expressed in units;

- PFI - protein and total body fat ratio index, expressed in $\mathrm{kg}$.

Statistical data analysis. All results were analyzed using the descriptive statistical procedure to calculate the basic measures of central tendency and dispersion of data (Mean, $\mathrm{SD}, \mathrm{cV} \%$, Std. Error, Skewness, Kurtosis, Min and Max, and $95 \%$ confidence interval). The normality of the distribution of the variables was tested using the nonparametric Kolmogorov-Smirnov (KS) test. The SPSS Statistics 19.0 software package was used for all statistical analyses (Hair et al., 1998).

\section{RESULTS}

The KS test results showed that there was no difference between the distribution for all variables and the hypothetically normal distribution as $\mathrm{Z}$ and $\mathrm{p}$ values fell within the range from $\mathrm{Z}=0.458, \mathrm{p}=0.985$ for Trunk FM variable to $Z=1.180, p=0.123$ for LAM variable. Such distribution normality of all tested variables indicated the 

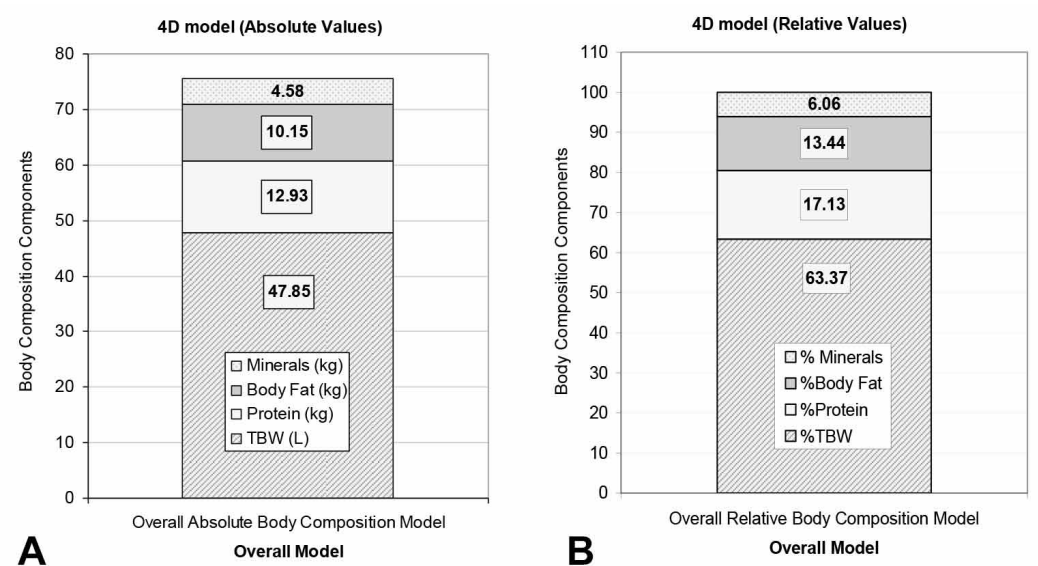

Fig. 1. Total absolute values (a) and relative values (b) of the 4D body composition model for top elite women volleyball players (in $\mathrm{kg}, \mathrm{L}$ or \%).

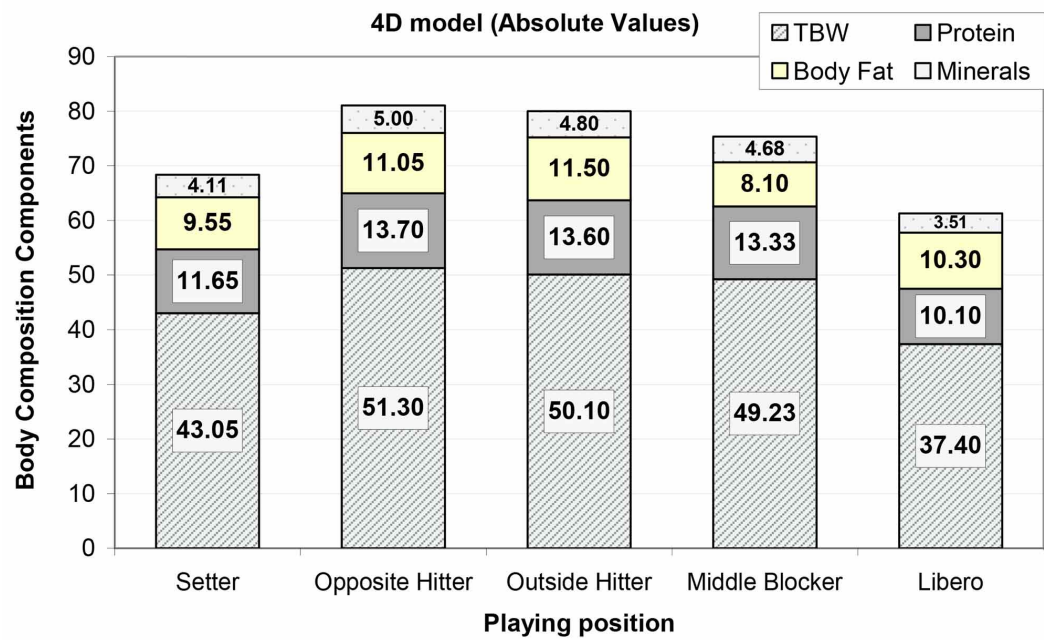

Fig. 2. Absolute values of the 4D body composition model for top elite women volleyball players defined according to the playing position (expressed in $\mathrm{kg}$ or L).

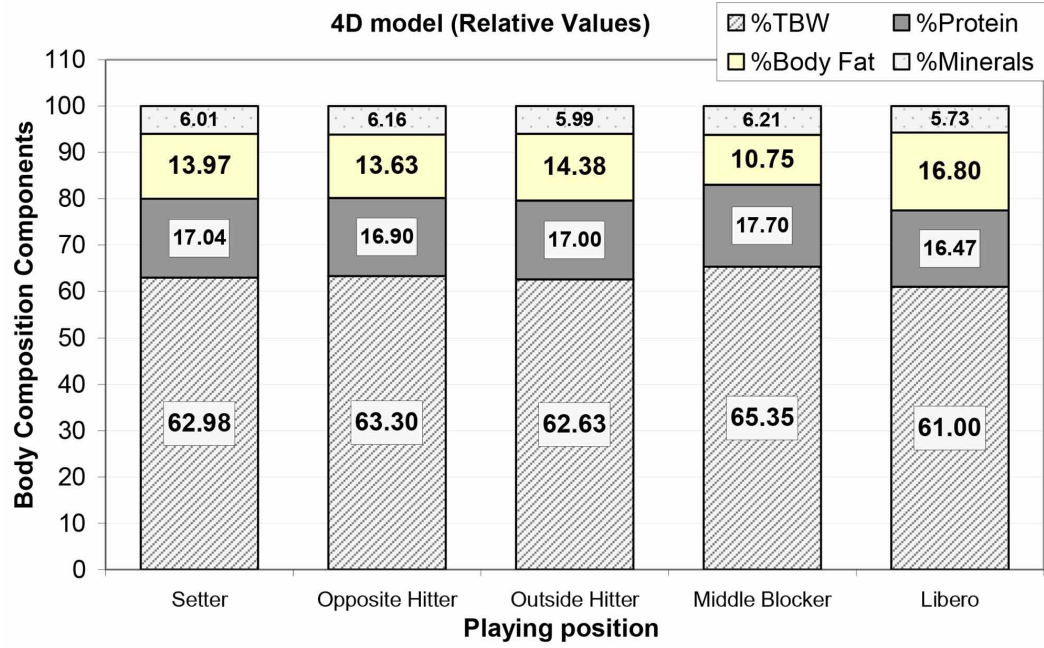

Fig. 3. Relative values of the 4D body composition model for top elite women volleyball players defined according to the playing position (expressed in \%). extraordinary homogeneity of the players relative to body composition, regardless of the relatively small and specifically selected sample.

Figures 1,2, and 3 show the results of the 4D body composition model for the tested women volleyball players. The results were collated according to absolute $(\mathrm{kg}$ and $\mathrm{L}$ ) and relative (\%) values for the tested variables (Fig. 1), and according to the playing position in the game (Figs. 2 and 3).

\section{DISCUSSION}

Modeling and controlling the body composition changes in the population of top athletes is vital not only as the study matter in sports science and the practical support in the training process, but also as a source of specific population sample data that can be compared with the general population through the national sample (Norton \& Olds; Dopsaj \& DjordjevicNikic). Athletes (Olympic, elite, national and regional) are mostly adolescent or adult people who have the ability to participate in physical activities and training and to compete in different individual or team, professional or amateur sports in a range of competitive games or races so that they could achieve best results (winning medals or setting records) at a sporting competition (Swann et al., 2015).

This team case study described various characteristics of the body composition in the sample of the women's Serbian national volleyball selection, the team that participated in the 2016 Rio Olympic Games and won the silver medal there. The aim of the study was to create an overall body composition model as well as a model for playing positions using multichannel segmental bioelectric impedance analysis.

With respect to body height (BH), it can be concluded that the mean values in the tested volleyball players were 
BANKOVIC, V.; DOPSAJ, M.; TERZIC, Z. \& NESIC, G. Descriptive body composition profile in female olympic volleyball medalists defined using multichannel bioimpedance measurement: Rio 2016 team case study. Int. J. Morphol., 36(2):699-708, 2018

Table I. Descriptive statistics of all tested variables across the overall sample of women volleyball players

\begin{tabular}{|c|c|c|c|c|c|c|}
\hline & $\begin{array}{l}\text { All Sample } \\
\qquad(\mathrm{N}=12)\end{array}$ & $\begin{array}{l}\text { Setter } \\
(\mathrm{N}=2)\end{array}$ & $\begin{array}{l}\text { Opposite Hitter } \\
(\mathrm{N}=2)\end{array}$ & $\begin{array}{l}\text { Outside Hitter } \\
\qquad(\mathrm{N}=4)\end{array}$ & $\begin{array}{l}\text { Middle Blocker } \\
\qquad(\mathrm{N}=3)\end{array}$ & $\begin{array}{l}\text { Liberc } \\
(\mathrm{N}=1)\end{array}$ \\
\hline $\mathrm{BH}(\mathrm{cm})$ & $188.93 \pm 6.49$ & $184.50 \pm 2.12$ & $195.55 \pm 1.77$ & $189.43 \pm 3.65$ & $192.13 \pm 1.42$ & 173.0 \\
\hline BM (kg) & $75.56 \pm 6.97$ & $68.35 \pm 2.47$ & $81.45 \pm 5.02$ & $79.98 \pm 3.28$ & $75.30 \pm 2.86$ & 61.3 \\
\hline TBW (L) & $47.85 \pm 4.52$ & $43.03 \pm 1.48$ & $51.30 \pm 2.83$ & $50.10 \pm 1.26$ & $49.23 \pm 1.55$ & 37.40 \\
\hline FFM (kg) & $50.19 \pm 6.70$ & $46.05 \pm 1.26$ & $52.12 \pm 1.24$ & $54.73 \pm 9.62$ & $46.15 \pm 4.31$ & 48.54 \\
\hline Protein $(k g)$ & $12.93 \pm 1.22$ & $11.65 \pm 0.35$ & $13.70 \pm 0.85$ & $13.60 \pm 0.35$ & $13.33 \pm 0.50$ & 10.10 \\
\hline BFM (kg) & $10.15 \pm 2.33$ & $9.55 \pm 0.35$ & $11.05 \pm 1.48$ & $11.50 \pm 2.92$ & $8.10 \pm 2.17$ & 10.3 \\
\hline SMM (kg) & $36.99 \pm 3.68$ & $33.10 \pm 1.13$ & $39.40 \pm 2.55$ & $38.93 \pm 1.05$ & $38.23 \pm 1.42$ & 28.5 \\
\hline RAM (kg) & $3.63 \pm 0.43$ & $3.09 \pm 0.22$ & $3.85 \pm 0.09$ & $3.84 \pm 0.18$ & $3.86 \pm 0.09$ & 2.73 \\
\hline RAF (kg) & $0.43 \pm 0.19$ & $0.50 \pm 0.00$ & $0.50 \pm 0.14$ & $0.48 \pm 0.24$ & $0.23 \pm 0.15$ & 0.50 \\
\hline LAM (kg) & $3.60 \pm 0.43$ & $3.05 \pm 0.14$ & $3.95 \pm 0.16$ & $3.79 \pm 0.16$ & $3.77 \pm 0.17$ & 2.72 \\
\hline LAF (kg) & $0.43 \pm 0.17$ & $0.45 \pm 0.07$ & $0.45 \pm 0.07$ & $0.50 \pm 0.22$ & $0.30 \pm 0.20$ & 0.50 \\
\hline Trunk LM (kg) & $28.36 \pm 2.52$ & $25.30 \pm 1.13$ & $30.00 \pm 0.71$ & $29.55 \pm 0.87$ & $29.57 \pm 0.65$ & 22.80 \\
\hline Trunk FM (kg) & $5.02 \pm 1.43$ & $4.40 \pm 0.28$ & $5.75 \pm 0.64$ & $5.88 \pm 1.82$ & $3.80 \pm 1.37$ & 5.00 \\
\hline RLM (kg) & $10.92 \pm 1.13$ & $10.07 \pm 0.23$ & $12.01 \pm 0.38$ & $11.28 \pm 0.47$ & $11.25 \pm 0.13$ & 8.01 \\
\hline RLF (kg) & $1.65 \pm 0.29$ & $1.60 \pm 0.00$ & $1.80 \pm 0.14$ & $1.80 \pm 0.36$ & $1.37 \pm 0.25$ & 1.70 \\
\hline LLM (kg) & $10.92 \pm 1.19$ & $9.96 \pm 0.23$ & $12.00 \pm 0.23$ & $11.35 \pm 0.38$ & $11.30 \pm 0.19$ & 7.83 \\
\hline LLF (kg) & $1.60 \pm 0.00$ & $1.6 \pm 0.00$ & $1.80 \pm 0.14$ & $1.78 \pm 0.38$ & $1.37 \pm 0.25$ & 1.60 \\
\hline BMI $\left(\mathrm{kg} \cdot \mathrm{m}^{-2}\right)$ & $21.08 \pm 1.30$ & $20.08 \pm 0.25$ & $21.32 \pm 1.70$ & $22.30 \pm 1.04$ & $20.40 \pm 0.77$ & 19.80 \\
\hline FFMI $\left(\mathrm{kg} \cdot \mathrm{m}^{2}{ }^{2}\right)$ & $18.27 \pm 0.98$ & $17.28 \pm 0.19$ & $18.32 \pm 1.39$ & $19.10 \pm 0.60$ & $18.22 \pm 0.80$ & 17.04 \\
\hline PFMI $\left(\mathrm{kg} \cdot \mathrm{m}^{2}{ }^{2}\right)$ & $0.374 \pm 0.094$ & $0.359 \pm 0.011$ & $0.326 \pm 0.018$ & $0.345 \pm 0.081$ & & 0.328 \\
\hline BFMI $\left(k g \bullet m^{-2}\right)$ & $2.85 \pm 0.68$ & $2.80 \pm 0.04$ & $2.89 \pm 0.44$ & $3.21 \pm 0.82$ & $2.19 \pm 0.56$ & 3.44 \\
\hline SMMI $\left(\mathrm{kg} \cdot \mathrm{m}^{-2}\right)$ & $10.34 \pm 0.62$ & $9.72 \pm 0.11$ & $10.31 \pm 0.85$ & $10.85 \pm 0.41$ & $10.36 \pm 0.51$ & 9.52 \\
\hline PMI $\left(\mathrm{kg} \cdot \mathrm{m}^{-2}\right)$ & $3.62 \pm 0.21$ & $3.42 \pm 0.03$ & $3.59 \pm 0.29$ & $3.79 \pm 0.14$ & $3.61 \pm 0.18$ & 3.37 \\
\hline PBF (\%) & $13.43 \pm 2.70$ & $13.97 \pm 0.01$ & $13.54 \pm 0.99$ & $14.31 \pm 3.09$ & $10.72 \pm 2.58$ & 16.80 \\
\hline PTBW (\%) & $63.33 \pm 2.00$ & $62.99 \pm 0.11$ & $63.00 \pm 0.41$ & $62.70 \pm 2.29$ & $65.41 \pm 1.93$ & 61.01 \\
\hline PSMM (\%) & $48.95 \pm 1.78$ & $48.43 \pm 0.10$ & $48.37 \pm 0.14$ & $48.72 \pm 1.91$ & $50.80 \pm 1.76$ & 46.49 \\
\hline PPM (\%) & $17.12 \pm 0.59$ & $17.05 \pm 0.10$ & $16.82 \pm 0.01$ & $17.02 \pm 0.65$ & $17.71 \pm 0.65$ & 16.48 \\
\hline PBF/BMI (iu) & $0.637 \pm 0.120$ & $0.696 \pm 0.008$ & $0.635 \pm 0.004$ & $0.639 \pm 0.115$ & & 0.848 \\
\hline PFI (kg) & $1.337 \pm 0.359$ & $1.220 \pm 0.008$ & $1.246 \pm 0.091$ & $1.236 \pm 0.287$ & & 0.981 \\
\hline
\end{tabular}

$188.93 \pm 6.49 \mathrm{~cm}$, with the highest $\mathrm{BH}$ of $195.55 \pm 1.77$ found in the position of Opposite Hitter and the lowest BH of 173.0 found in Libero (Table I). Previous studies also observed statistically significantly lowest BH in players in the position of Libero, while the players in the position of Opposite Hitter, Outside Hitter and Middle Blocker were statistically significantly taller than the players in the other positions were (Palao et al.; Mielgo-Ayuso et al.).

A general overview for the period 2000-2012 revealed an increase in body height in elite women volleyball players, members of national teams participating in the Olympic Games and World Championships. Although statistically not significant, this increase of $0.11 \mathrm{~cm}$ per major world competition (OG and WC) was observed per every two calendar years, with $\mathrm{R}^{2}$ at the level of $22.50 \%$ of the explained variance (Palao et al.). Also, it was established that body height was one of the dominant anthropometric characteristics that profiled successful teams in the Olympic Games and World Championships, compared to less successful teams (the average $\mathrm{BH}$ across team rankings was $1.84 \pm 0.08 \mathrm{~m}$ for the $1 \mathrm{st}-4$ th ranked, $1.83 \pm 0.08 \mathrm{~m}$ for the 5 th -8 th ranked, and $1.82 \pm 0.08 \mathrm{~m}$ for the 9 th - the last ranked). In relation to playing positions in the function of ranking, statistically significant differences were established only in the Middle Blocker, Opposite Hitter, and Outside Hitter, while no difference in $\mathrm{BH}$ in relation to ranking was found for the positions of Setter and Libero (Palao et al.).

Similar data were also supported by the results from the 2016 Rio Olympic Games, in which statistically significant regression dependence was established between the average body height in the team players and the final rankings, at $\mathrm{R}^{2}=0.3876, \mathrm{~F}=6.33$, and $\mathrm{p}=0.031$ (Dopsaj, 2016). In particular, at the 2016 Rio Olympic Games with 12 of the world's best teams playing in the volleyball tournament, the average body height of the whole team was an independent factor, participating in the prediction of the final placement with as much as $38.76 \%$ (Fig. 4). 


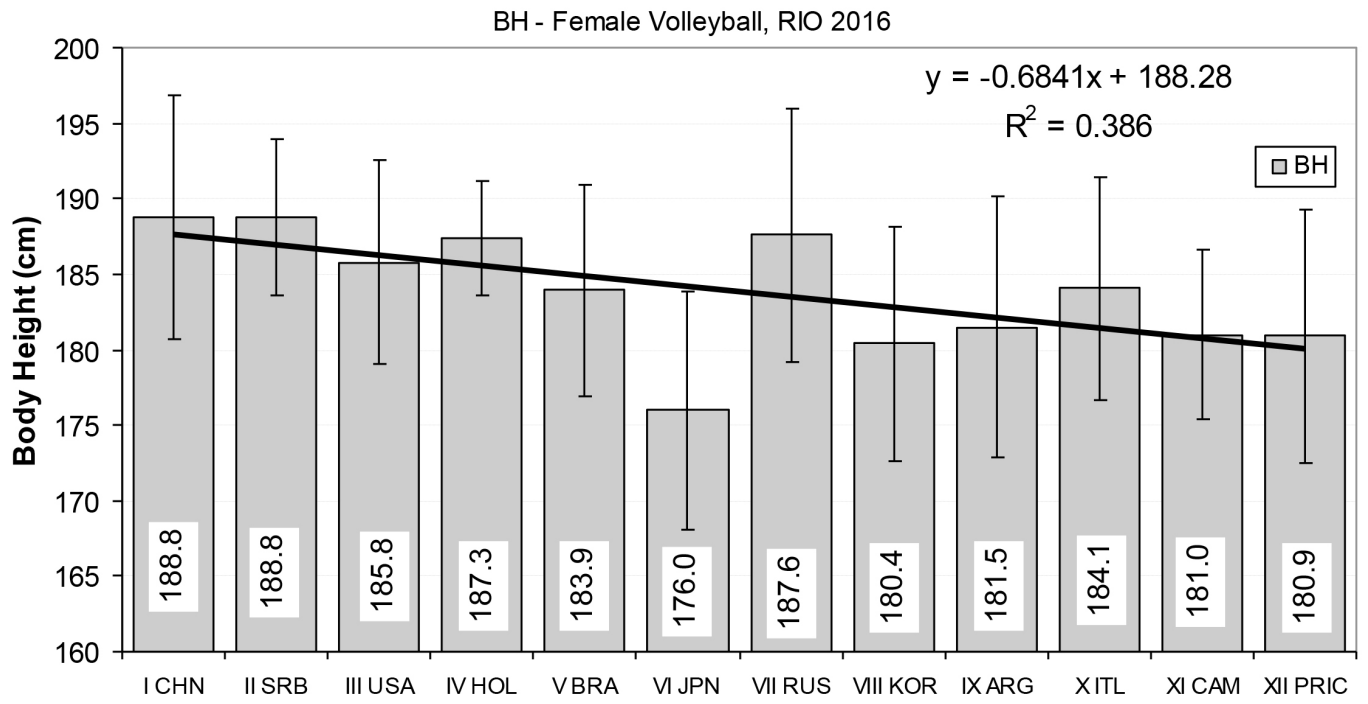

Final Teams OG Rio 2016 tournament position

Fig. 4. The relation between women volleyball players' average $\mathrm{BH}$ and final tournament rankings at the Rio 2016 Olympic Games.

The importance of physical stature for the future of volleyball in women is also indicated by the fact that the average height of the first four teams at the 2016 Rio Olympic Games was $187.6 \mathrm{~cm}$, and in the teams ranked fifth to eighth it was $182.0 \mathrm{~cm}$, while in the four last ranked teams it was $181.9 \mathrm{~cm}$ (Dopsaj). Also, the analysis of body height for all participants in the final volleyball tournament of the 2016 Rio Olympic Games $(\mathrm{N}=144)$ revealed that the average height for all the women players was $183.8 \pm 7.9 \mathrm{~cm} ; 1.39 \%$ of the players were above $2.0 \mathrm{~m}$ tall, $5.56 \%$ were between $1.95 \mathrm{~m}$ and $1.99 \mathrm{~m}$ tall, $21.53 \%$ were between $1.90 \mathrm{~m}$ and $1.94 \mathrm{~m}$ tall, $20.14 \%$ were between $1.85 \mathrm{~m}$ and $1.89 \mathrm{~m}$ tall,
$25.0 \%$ were between $1.80 \mathrm{~m}$ and $1.84 \mathrm{~m}$ tall, $13.89 \%$ were between $1.75 \mathrm{~m}$ and $1.79 \mathrm{~m}$ tall, $7.64 \%$ were between 1.70 $\mathrm{m}$ and $1.74 \mathrm{~m}$ tall, while only $4.86 \%$ of the players were below $1.69 \mathrm{~m}$ tall. Overall, $6.9 \%$ of the players were over $1.95 \mathrm{~m}$ tall, while $66.67 \%$ of the players were between 1.80 $\mathrm{m}$ and $1.94 \mathrm{~m}$ tall (Dopsaj). According to the mathematical modeling of the stature prediction based on the average height of the three best ranked teams from the last three Olympic Games, it was calculated that the hypothetical average stature of the future women's volleyball medalists at the 2020 Tokyo OG and 2024 OG was likely to be 187.5 and 189.1, respectively (Dopsaj).

Table II. Overview of the primary characteristics of body composition in top elite women volleyball players

\begin{tabular}{|c|c|c|c|c|c|}
\hline Team & & $\begin{array}{l}\mathrm{BH} \\
(\mathrm{cm})\end{array}$ & $\begin{array}{l}\mathrm{BM} \\
(\mathrm{kg})\end{array}$ & $\begin{array}{c}\text { BMI } \\
\left(\mathrm{kg} \bullet \mathrm{m}^{-2}\right)\end{array}$ & $\begin{array}{c}\text { \%Body Fat } \\
(\%)\end{array}$ \\
\hline Serbia (Actual study) & National team & $188.93 \pm 6.49$ & $75.56 \pm 6.97$ & $21.08 \pm 1.30$ & $13.43 \pm 2.70$ \\
\hline Greece (Papadopoulos, 2003) & National team & $180.5 \pm 6.2$ & $74.6 \pm 8.2$ & 22.90 & \\
\hline Russia (Aytek, 2007) & National team & 183.41 & & & \\
\hline Brasil (Aytek, 2007) & National team & 189.33 & & & \\
\hline Turkey (Aytek, 2007) & National team & $183.25 \pm 6.15$ & $67.43 \pm 4.80$ & $19.93 \pm 1.00$ & $15.86 \pm 3.11$ \\
\hline Croatia (Grgantov et al., 2008) & Elite & $181.73 \pm 6.94$ & & & \\
\hline Slovakia (Malá et al., 2010) & Elite & $179.42 \pm 7.32$ & $67.75 \pm 5.90$ & 21.05 & $13.72 \pm 2.42$ \\
\hline China (Zhang, 2010) & Elite & $183.60 \pm 5.77$ & $70.5 \pm 7.6$ & 20.91 & \\
\hline Czech Republic(Mal et al. 2011) & Elite & $183.40 \pm 6.56$ & $72.23 \pm 6.21$ & $21.60 \pm 1.85$ & $15.47 \pm 1.03$ \\
\hline Cuba (Carvajal et al., 2012) & National team & $181.6 \pm 3.9$ & $75.2 \pm 5.8$ & 22.80 & \\
\hline Poland (Zapolska et al., 2014) & National team & $180.0 \pm 10.0$ & 74.33 & 21.90 & $18.49 \pm 5.02$ \\
\hline Spain (Mielgo-Ayuso et al., 2015) & Elite & $179.68 \pm 7.26$ & $71.44 \pm 6.91$ & $22.15 \pm 1.11$ & \\
\hline AVG All & & $182.90 \pm 3.28$ & $72.12 \pm 3.09$ & $21.59 \pm 0.96$ & $15.39 \pm 2.03$ \\
\hline
\end{tabular}


Presently, there is significant scientific evidence (Table II) that suggests that top elite women volleyball players generally represent the ectomorph body type, with highly pronounced longitudinal dimensions, particularly body height, and a low BMI accompanied by borderline body fat values with reference to other athletes as well as to competitive success levels in volleyball performance (Norton \& Olds; Grgantov et al., 2008; Zang, 2010; Palao et al.; Mielgo-Ayuso et al.).

The highly remarkable average body height of the tested team of women players, despite the relatively small selection pool in the general population of the Republic of Serbia (approximately 7 million), may be explained by the fact that the Serbian nation generally belongs to the category of tall nations (Grasgruber et al., 2014; Grasgruber et al., 2017). Based on the publications by Grasgruber et al. (2014, 2017) on the physical stature in men in Europe and Bosnia and Herzegovina, and in the population of the former Yugoslavia (Bosnia and Herzegovina, Montenegro, Serbia and Croatia), the tallest stature can be found among the population of Bosnia and Herzegovina. The influence of the genetic factor is vital, especially in view of high animal protein-rich diet that dominates in this area, which is highly correlated with the frequency of Y haplotype I-M170 and the combined frequency of Y haplotype I-M170 + R1b-U106 on the one hand, and male physical stature on the other (Grasgruber et al., 2014). Namely, according to the research, Serbs, Croats, and the population of Bosnia and Herzegovina shared a similar frequency of Y haplotype I-M170 of 45-50 $\%$, while in the population of Herzegovina (which is a part of Bosnia and Herzegovina, located in the area of the Dinaric Alps that stretch through the territories of the former Yugoslavia: Bosnia and Herzegovina, Montenegro and Croatia) it was $70.9 \%$. Highly relevant to the correlation between genetic factors and body height are also the extensive migrations of the population from Herzegovina and Montenegro to the northern regions of the Balkan Peninsula, particularly to Serbian parts, especially in the period of the Ottoman Empire, from the fourteenth to the twentieth centuries (Cvijic, 2000).

The overall mean BM for the Serbian team was $75.56 \pm 6.97 \mathrm{~kg}$; the lowest value was $61.3 \mathrm{~kg}$ in the position of Libero, while the highest result was $81.54 \pm 5.02 \mathrm{~kg}$ in the position of Opposite Hitter (Table I). Similarly, the overall mean BMI for the team was $21.08 \pm 1.30 \mathrm{~kg} \bullet \mathrm{m}^{-2}$; the lowest value was $19.80 \mathrm{~kg} \cdot \mathrm{m}^{-2}$ in the position of Libero, but the highest result of $22.30 \pm 1.04 \mathrm{~kg} \bullet \mathrm{m}^{-2}$ was observed in the position of Outside Hitter (Table I).

However, the results for BM and BMI status and change trends were inversely proportional to those for $\mathrm{BH}$.
Thus, while the mean $\mathrm{BH}$ in women volleyball players has increased in the past 50 years (Palao et al.), BM and BMI in particular have declined. Namely, in the period 2000-2012, elite national team volleyball players participating in the Olympic Games and the World Championships showed a statistically significant decrease in BM and BMI of -0.332 $\mathrm{kg}$ and $-0.146 \mathrm{~kg} \bullet \mathrm{m}^{-2}$ per major world competition (OG and WC), i.e., per every two calendar years, with $\mathrm{R}^{2}$ at the level of $66.65 \%, p=0.025$ and $81.13 \%, p=0.006$ of the explained variance, respectively (Palao et al.). In other words, the world's top women volleyball players have been selected and trained so that they have become taller but leaner. For the needs of sports science and training technology, it is necessary to include new body composition indexes in the function of controlling the levels of preparedness and competitive performance that can be more sensitive to the condition of the elements of the body composition important for achieving top sporting results.

Thus, it is necessary for practice to innovate by the inclusion of a range of body composition indexes that are dependant on voluminosity and longitudinality (Dopsaj et al., 2017), and control the condition of the body composition by using the method of individual approach (Nikolaidis et al.).

With respect to the variables that defined body composition relative to the contractile structure, i.e., the variables that defined protein mass, skeletal muscle mass and lean body mass (Protein, SMM, FFM), the mean values were $12.93 \pm 1.22 \mathrm{~kg}, 36.99 \pm 3.68 \mathrm{~kg}$ and $50.19 \pm 6.70 \mathrm{~kg}$, respectively (Table I, Fig. 1a). The highest Protein and SMM values were detected in the position of Opposite Hitter (Table I, $13.70 \pm 0.85$ and $39.40 \pm 2.55 \mathrm{~kg}$ ), while the highest FFM was detected in Outside Hitter (54.73 \pm 9.62$)$. The lowest Protein and SMM values were observed in Libero $(10.10 \mathrm{~kg}$ and $28.50 \mathrm{~kg}$, respectively), while the lowest FFM was found in the Setter position (Table I, 46.05 $\pm 1.26 \mathrm{~kg}$ ). To a certain extent, these values resulted from the players' characteristic morphological type and subtypes in relation to their position in the game, but they were also most likely influenced by specialization in the selection for the technical and tactical tasks in the game, or by physical adaptation to specialization in the training for top elite volleyball players (Grgantov et al.; Nikolaidis et al.; Mielgo-Ayuso et al.).

It can be argued that compared to the indicators in the general athletic population, the absolute values for the elite volleyball players in our sample were by $2.19 \mathrm{~kg}$ or $20.39 \%$ higher in contractile mass, i.e., protein mass, and by $6.56 \mathrm{~kg}$ or $21.56 \%$ higher in SMM mass than for other top Serbian women athletes. The relative values for body voluminosity showed that for the tested volleyball players, the PPM and PSMM variables were by $7.47 \%$ and $8.83 \%$ 
higher, respectively, compared to other top women athletes from Serbia (Dopsaj \& Djordjevic-Nikic). Similarly, the comparison of the ballast tissue values revealed that the absolute body fat variables for the tested volleyball players were by $3.27 \mathrm{~kg}$, or $24.37 \%$, lower in body fat mass, and by $31.27 \%$ lower in percent of body fat than for other top Serbian women athletes (Dopsaj \& Djordjevic-Nikic). The values for the relative percent body fat, $\mathrm{PBF}$, for the tested sample were remarkably low at $13.43 \%$, ranging from $10.36 \%$ for players in the position of Middle Blocker to $16.18 \%$ for the position of Libero (Table I). Compared to ACSM and ACE standards, the tested players' $\mathrm{PBF}$ was above $90^{\text {th }}$ percentile for the young female population. According to biological criteria, this bordered the essential body fat percentage (between $10.0 \%$ and $13.0 \%$ body fat) (Whaley et al., 2006; Digate Muth, 2009).

Partialization of the contractile and ballast tissue variables with respect to longitudinality (Table I) revealed that the mean value for the respondents' body skeletal muscle index (SSMI) was $10.34 \mathrm{~kg} / \mathrm{m}^{2}$, their body protein mass index (PMI) was $3.62 \mathrm{~kg} / \mathrm{m}^{2}$, their lean mass index (FFMI) was $18.27 \mathrm{~kg} / \mathrm{m}^{2}$, while their total body fat mass index (BFMI) was $2.85 \mathrm{~kg} / \mathrm{m}^{2}$. In comparison to previously published results for top women athletes, our respondents had higher FFMI values $\left(\mathrm{POR}=16.24 \mathrm{~kg} \bullet \mathrm{m}^{2}\right.$ ), but lower FMI values $\left(\mathrm{POR}=5.09 \mathrm{~kg} \bullet \mathrm{m}^{2}\right)$ than top Portuguese women volleyball players (Santos et al.).

The value of the index that describes the relationship between the contractile and ballast tissue, i.e., protein and fat ratio (PFI), was $1.337 \mathrm{~kg}$, while the index in the function of longitudinality (PFMI) was $0.374 \mathrm{~kg}$ protein per kilogram of fat per $\mathrm{m}^{2}$ of body height.

The segmental body composition analysis showed that the segmental lean mass of the right and left arms was $3.63 \mathrm{~kg}$ and $3.60 \mathrm{~kg}$, respectively (RAM and LAM), with absolutely proportional fat mass values of $0.43 \mathrm{~kg}$ per each segment (RAF and LAF, Table I). The segmental lean mass values for the right and left legs were also absolutely proportional at $10.92 \mathrm{~kg}$, while the fat mass was 1.65 and $1.60 \mathrm{~kg}$, respectively. The segmental lean mass of the trunk was $28.36 \mathrm{~kg}$, with the fat mass of $5.02 \mathrm{~kg}$ (Table I). If these results are analyzed in mean relative values for the segmental lean mass, it can be argued that $49.38 \%$ accounted for the trunk, $6.32 \%$ and $6.27 \%$ for the right and left arms, respectively, while $19.01 \%$ was distributed in the legs. As for the fat mass, $4.71 \%$ accounted for the arms, $54.98 \%$ for the trunk, while $18.07 \%$ and $17.52 \%$ was distributed on the right and left legs, respectively.

In reference to the accepted standards in healthy individuals, it can be argued that the FFM values measured in the test sample $\left(50.19 \mathrm{~kg}\right.$, Table I) were above the $95^{\text {th }}$ percentile $(95 \%)$ of the standard, while the BFM values $(10.15$ $\mathrm{kg}$ ) were at the level of the $10^{\text {th }}$ percentile $(10 \%$ o of the standard for healthy women of the same age (Kyle et al.).

Upon a thorough analysis of the results of the study, it can be argued that in all measured anthropomorphological characteristics the top elite women volleyball players from the tested sample had a body type of remarkable basic longitudinality, i.e., physical stature, and a body composition mainly characterized by pronounced muscle mass and a very small amount of body fat. Volleyball is a game dominated by short-lasting submaximal and maximal stresses with a large number of repetitions of high standing and running jumps, fast and short complex and simple movements, and high intensity agility actions. As the focus of the game shifts towards increasing the height, the speed of service and technical and tactical actions, and the game efficiency and its interrelatedness with individual positions, it is obvious that the training tools (power and speed training, food control, etc.) and the selection system need to adapt, and in fact constitute the trend in developing top elite women volleyball (Gabbett et al.; Nikos et al., 2009; Schaun et al.; Palao et al.; Mielgo-Ayuso et al.). Finally, it is possible to assume that the women volleyball players of the future will have developed an anatomical and physiogical foundation for an adequate anthropometric and physical status in order to respond to the increasing selection and adaptation requirements of the future game. In this sense, it is likely that the trend in anthropomorphological development of top elite volleyball players will shift from the predominantly ectomorph towards the combined, distinctly tall ectomesomorph and tall mesomorph body types, especially in the positions of Middle Blocker, Opposite Hitter and Outside Hitter, with a similar tendency in the position of Setter.

\section{CONCLUSION}

The subject of this paper was the study of the morphological status of top elite women volleyball players, Rio 2016 Olympic medal winners, with the aim of obtaining reliable quantitative data to be used to determine the morphological model and control the morphological status of elite women volleyball players. The results obtained in the study and the body composition model defined upon the observed variables can further be used to lay the foundations for the system of monitoring the quantitative characteristics in elite women volleyball players during the main competition season of the Olympic cycle, or any other preparation cycle for elite world and continental championships. 
The presented mean values for body height in the sample of elite women volleyball players were $188.93 \pm 6.49$ $\mathrm{cm}$, with the tallest players in the position of Opposite Hitter (mean $\mathrm{BH}=195.55 \pm 1.77$ ) and the shortest stature in the position of Libero (mean $\mathrm{BH}=173.0$ ). The overall mean BM value for the Serbian team was $75.56 \pm 6.97$, while the overall mean BMI value for the team was $21.08 \pm 1.30 \mathrm{~kg} \bullet \mathrm{m}^{-2}$.

With respect to the variables that defined body composition relative to the contractile structure, i.e., the variables that defined protein mass, skeletal muscle mass and lean body mass (Protein, SMM, FFM), the mean values were $12.93 \pm 1.22 \mathrm{~kg}, 36.99 \pm 3.68 \mathrm{~kg}$ and $50.19 \pm 6.70 \mathrm{~kg}$, respectively. The mean fat mass value for the team, i.e., ballast mass was $10.15 \pm 2.33 \mathrm{~kg}$, while the percentage of body fat (PBF) was at the level of $13.43 \pm 2.70 \%$.

The segmental body composition analysis showed that the mean relative value for the segmental lean body mass was distributed as follows: $49.38 \%$ accounted for the trunk, $6.32 \%$ and $6.27 \%$ for the right and left arms, respectively, while $19.01 \%$ accounted for the legs. As for the fat mass, $4.71 \%$ accounted for the arms, $54.98 \%$ for the trunk, while $18.07 \%$ and $17.52 \%$ was distributed in the right and left legs, respectively.

Partialization of the contractile and ballast tissue variables with respect to longitudinality revealed that the mean value for the respondents' body skeletal muscle index (SSMI) was $10.34 \mathrm{~kg} / \mathrm{m}^{2}$, their body protein mass index (PMI) was $3.62 \mathrm{~kg} / \mathrm{m}^{2}$, their lean mass index (FFMI) was $18.27 \mathrm{~kg} / \mathrm{m}^{2}$, while their total body fat mass index (BFMI) was $2.85 \mathrm{~kg} / \mathrm{m}^{2}$. The value of the index that describes the relationship between the contractile and ballast tissue, i.e., protein and fat ratio (PFI), was $1.337 \mathrm{~kg}$, while the index in the function of longitudinality (PFMI) was $0.374 \mathrm{~kg}$ protein per kilogram of fat per $\mathrm{m}^{2}$ of body height.

Upon a thorough analysis of the results of the study, it can be argued that in all measured anthropomorphological characteristics the top elite women volleyball players from the tested sample had a body type of remarkable basic longitudinality, i.e., physical stature, and a body composition mainly characterized by very high muscle mass but such a low amount of body fat that it was close to the biological minimum for women.

With respect to the complete analysis, it is possible to assume that the women volleyball players of the future will have developed an anatomical and physiogical foundation for an adequate anthropometric and physical status, in order to respond to the increasing selection and adaptation requirements of the future game. In this sense, it is likely that the trend in anthropomorphological development of top elite volleyball players will shift from the predominantly ectomorph towards the combined, distinctly tall ectomesomorph and tall mesomorph body type, especially in the positions of Middle Blocker, Opposite Hitter and Outside Hitter, with a similar tendency in the position of Setter.

\section{ACKNOWLEDGEMENTS}

The paper is a part of the project "Effects of the Applied Physical Activity on Locomotor, Metabolic, Psychosocial and Educational Status of the Population of the Republic of Serbia", number III47015, funded by the Ministry of Education, Science and Technological Development of the Republic of Serbia - Scientific Projects 2011 - 2017 Cycle.

BANKOVIC, V.; DOPSAJ, M.; TERZIC, Z. \& NESIC, G. Perfil descriptivo de la composición corporal en medallistas femeninos de voleibol olímpico definido mediante medición de bioimpedancia multicanal: Estudio del equipo Rio 2016. Int. J. Morphol., 36(2):699-708, 2018.

RESUMEN: El objetivo de este trabajo fue estudiar el estado morfológico de las jugadoras de voleibol de élite, ganadoras de la medalla olímpica Rio 2016 y obtener datos cuantitativos confiables para determinar el modelo morfológico y controlar el estado morfológico de las mejores jugadoras de voleibol de elite. Este estudio estudió a 12 jugadoras de voleibol de élite que participaron en los Juegos Olímpicos de Rio 2016 y ganaron la medalla de plata. Las mediciones de la composición corporal se realizaron un día antes de partir para los Juegos Olímpicos de Río, el 25 de junio del año 2016. Se realizó un análisis de bioimpedancia eléctrica (ABI), con el analizador de sistema de electrodos táctiles Tetrapolar 720 de 8 puntos. El estudio incluyó 29 variables: 17 variables originales, cuatro variables dependientes de voluminosidad, seis variables dependientes de la longitud y dos variables de índice combinadas. Los resultados mostraron que la estatura promedio de las jugadoras fue de $188,93 \pm 6,49 \mathrm{~cm}$, el valor medio general de MC para el equipo serbio fue de 75,56 \pm 6,97 , el valor medio total de IMC para el equipo fue de 21,08 \pm $1,30 \mathrm{~kg} \cdot \mathrm{m}^{-2}$, mientras que los valores medios para el porcentaje de músculos esqueléticos y la masa corporal fueron $48.95 \pm 1.78$ $\%$ y $13.43 \pm 2.70 \%$, respectivamente. Tras un análisis exhaustivo de los resultados del estudio, se puede argumentar que en todas las características antropomorfológicas medidas, las jugadoras de élite de voleibol femenino, de la muestra analizada, tenían un tipo corporal de notable longitudinalidad básica, por ejemplo, AC y una composición corporal caracterizada principalmente por una masa muscular muy alta, pero una cantidad tan baja de grasa corporal que limita con el mínimo biológico para las mujeres.

PALABRAS CLAVE: Impedancia bioeléctrica; Atletas femeninas; Voleibol; Composición corporal. 


\section{REFERENCES}

Ackland, T. R.; Lohman, T. G.; Sundgot-Borgen, J.; Maughan, R. J.; Meyer, N. L.; Stewart, A. D. \& Müller, W. Current status of body composition assessment in sport: review and position statement on behalf of the ad hoc research working group on body composition health and performance, under the auspices of the I.O.C. Medical Commission. Sports Med., 42(3):227-49, 2012.

Aytek, A. I. Body composition of Turkish volleyball players. In: Intensive Course in Biological Anthropology 1st Summer School of the European Anthropological Association 16-30 June, 2007, Prague, Czech Republic. EAA Summer School eBook, 1:203-8, 2007.

Carvajal, W.; Betancourt, H.; León, S.; Deturnel, Y.; Martínez, M.; Echevarría, I.; Castillo, M. E. \& Serviat, N. Kinanthropometric profile of Cuban women Olympic volleyball champions. MEDICC Rev., 14(2):16-22, 2012.

Cvijic, J. Anthropogeographic and Ethnographic Documents. Collected Works. Belgrade, Institute for Textbooks, Vol. 1, Book IV, 2000. pp.131210.

Digate Muth, N. What are the guidelines for percentage of body fat loss? San Diego, American Council of Exercise (ACE), 2009. Available grom: https://www.acefitness.org/acefit/healthy-living-article/60/112/what-arethe-guidelines-for-percentage-of-body-fat

Dopsaj, M. \& Dojordjevic-Nikic, M. Basic body structure characteristics of the elite Serbian athletes measured by the method of multisegmental bioelectrical impedance. Serb. Sci. Today., 1(2):276-84, 2016.

Dopsaj, M. Anthropometrics and Body Composition Model of Female Volleyball Players: Recommendations for the future. Belgrade, Internal Scientific Report, Volleyball Federation of Serbia, 2016.

Dopsaj, M.; Ilic, V.; Djordjevic-Nikic, M.; Vukovic, M.; Eminovic, F.; Macura, M. \& Ilic, D. Descriptive model and gender dimorphism of body structure of physically active students of Belgrade University: Pilot study. The Anthropologist, 19(1):239-48, 2015.

Dopsaj, M.; Markovic, M.; Kasum, G.; Jovanovic, S.; Koropanovski, N.; Vukovic, M. \& Mudric, M. Discrimination of different body structure indexes of elite athletes in combat sports measured by multi frequency bioimpedance method. Int. J. Morphol., 35(1):199-207, 2017.

Esco, M. R.; Snarr, R. L.; Leatherwood, M. D.; Chamberlian, N. A.; Redding, M. L.; Flatt, A. A.; Moon, J. R. \& Williford, H. N. Comparison of total and segmental body composition using DXA and multifrequency bioimpedance in collegiate female athletes. J. Strength Cond. Res., 29(4):918-25, 2015.

Eston, R. G. \& Reilly, T. (Eds.). Kinanthropometry and Exercise Physiology Laborytory Manual: Tests, Procedures and Data. Volume 1: Antropometry. New York, Routledge, 2009.

Formetti, W. C.; Pivarnik, J. M.; Foley, J. M. \& Fiechtner, J. J. Reliability and validity of body composition measures in female athletes. J. Appl. Physiol. (1985), 87(3):1114-22, 1999.

Gabbett, T.; Georgieff, B. \& Domrow, N. The use of physiological, anthropometric, and skill data to predict selection in a talent-identified junior volleyball squad. J. Sports Sci., 25(12):1337-44, 2007.

Grasgruber, P.; Cacek, J.; Kalina, T. \& Sebera, M. The role of nutrition and genetics as key determinants of the positive height trend. Econ. Hum. Biol., 15:81-100, 2014.

Grasgruber, P.; Popovic, S.; Bokuvka, D.; Davidovic, I.; Hrebícková, S.; Ingrová, P.; Potpara, P.; Prce, S. \& Stracárová N. The mountains of giants: an anthropometric survey of male youths in Bosnia and Herzegovina. $R$. Soc. Open Sci., 4(4):161054, 2017.

Grgantov, Z.; Krstulovic, S. \& Zuvela, F. Relationships between Anthropometrics and Estimated Overall Quality in Female Volleyball Players. In: Milanovic, D \& Prot, F. (Eds.). Proceedings Book, $5^{\text {th }}$ International Scientific Conference on Kinesiology "Kinesiology Research Trends and Applications". Zagreb, Faculty of Kinesiology, University of Zagreb, 2008. pp.910-2.

Hair, J.; Anderson, R.; Tatham, R. \& Black, W. Multivariate Data Analysis. $5^{\text {th }}$ ed. New Jersey, Prentice-Hall Inc., 1998.
InBody 720. The Precision Body Composition Analyzer, Instruction Manual, 1996-2008. Seoul, Biospace Co. Ltd., 2008.

Kyle, U. G.; Genton, L.; Slosman, D. O. \& Pichard, C. Fat-free and fat mass percentiles in 5225 healthy subjects aged 15 to 98 years. Nutrition, 17(78):534-41, 2001.

Malá, L.; Maly, T.; Záhalka, F. \& Bunc, V. The profile and comparison of body composition of elite female volleyball players. Kinesiology, 42(1):90-7, 2010.

Malousaris, G. G.; Bergeles, N. K.; Barzouka, K. G.; Bayios, I. A.; Nassis, G. P. \& Koskolou, M. D. Somatotype, size and body composition of competitive female volleyball players. J. Sci. Med. Sport, 11(3):337-44, 2008.

Maly, T.; Malá, L.; Zahálka, T.; Balás, J. \& Cada, M. Comparison of body composition between two elite women's volleyball teams. Acta Univ. Palacki. Olomuc. Gymn., 41(1):15-22, 2011.

Mielgo-Ayuso, J.; Calleja-González, J.; Clemente-Suárez, V. J. \& Zourdos, M. C. Influence of anthropometric profile on physical performance in elite female volleyballers in relation to playing position. Nutr. Hosp., 31(2):84957, 2015.

Nikolaidis, P. T.; Ziv, G.; Arnon, M. \& Lidor, R. Physical characteristics and physiological attributes of female volleyball players--the need for individual data. J. Strength Cond. Res., 26(9):2547-57, 2012.

Nikos, B.; Karolina, B. \& Elissavet, N. M. Performance of male and female setters and attackers on Olympic-level volleyball teams. Int. J. Perform. Anal. Sport, 9(1):141-8, 2009.

Norton, K. \& Olds, T. Morphological evolution of athletes over the $20^{\text {th }}$ century: causes and consequences. Sports Med., 31(11):763-83, 2001.

Palao, J. M.; Manzanares, P. \& Valadés, D. Anthropometric, physical, and age differences by the player position and the performance level in volleyball. J. Hum. Kinet., 44:223-36, 2014.

Papadopoulous, S. Anthropometric Characteristics and Body Composition of Greek Elite Women Volleyball Players. In: De Ridder, H. \& Olds, T. (Eds.). Kinanthropometry. Potchefstroom, North-West University, 2003. pp.5-18.

Santos, D. A.; Dawson, J. A.; Matias, C. N.; Rocha, P. M.; Minderico, C. S.; Allison, D. B.; Sardinha, L. B. \& Silva, A. M. Reference values for body composition and anthropometric measurements in athletes. PLoS One, 9(5):e97846, 2014

Schaun, G. Z.; Ribeiro, Y. S.; Vaz, M. S. \& Del Vecchio, F. B. Correlation between agility, lower limb power and performance in a sport-specific test in female volleyball players. Int. J. Sports Sci., 3(5):141-6, 2013.

Swann, C.; Moran, A. \& Piggott, D. Defining elite athletes: Issues in the study of expert performance in sports psychology. Psychol. Sport Exerc., 16(1):3$14,2015$.

Whaley, M. H.; Brubaker, P. H.; Otto, R. M. \& Armstrong, L. E. ACSM's Guidelines for Exercise Testing and Prescription. $7^{\text {th }}$ ed. Philadelphia, Lippincott Williams \& Wilkins, 2006.

Zapolska, J.; Witczyk, K.; Manczuk, A. \& Ostrowska, L. Assessment of nutrition, supplementation and body composition parameters on the example of professional volleyball players. Rocz. Panstw. Zakl. Hig., 65(3):235-42, 2014.

Zhang, Y. An investigation on the Anthropometry Profile and its Relationship with Physical Performance of Elite Chinese Women Volleyball Players. M.Sc. Thesis. Lismore, Southern Cross University, 2010.

\section{Corresponding author: \\ Vladimir Bankovic \\ Volleyball Federation of Serbia \\ Terazije 35/II, 11000 \\ Belgrade \\ SERBIA}

Email: vanjacoach@gmail.com

Received: 23-10-2017 Accepted: 24-01-2018 